\title{
COMMUNITY'S PERCEPTIONS AND ENTHUSIASM: EMPOWERING INFORMATION TECHNOLOGY AS MARKETING STRATEGY IN HOMECARE SERVICES
}

\author{
Yoyok Bekti Prasetyo*, Kumboyono**, Nina Septi Wardani** \\ *Department of community health nursing, Muhammadiyah University of Malang \\ **Department of community health nursing, Brawijaya University of Malang \\ E-mail: yoyok@umm.ac.id
}

\begin{abstract}
ABSTRAK
Pendahuluan: Persepsi masyarakat dan antusias terhadap pelayanan home care menjadi tantangan bagi homecare agency. Strategi yang mudah dan efektif adalah dengan menggunakan sistem informasi. Metode: Penelitian ini menggunakan desain analisis deskriptif di mana persepsi dan antusiasme masyarakat diukur dengan mengisi kuesioner $(r=0,367$; validitas dan reliabilitas $=0,734$ dan 0,777 ), di mana analisis data menggunakan correlation product moment dan $t$ test. Hasil: Analisis univariat menunjukkan persepsi terhadap pelayanan homecare dalam masyarakat internal adalah: rerata $=19,8$; rentang 17-24, sedangkan dalam masyarakat eksternal adalah: rerata $=19,53$; rentang $15-24$. Di sisi lain, antusiasme terhadap pelayanan homecare dalam masyarakat internal adalah: rerata $=31,33$; rentang $=28-36$, sedangkan masyarakat eksternal menghasilkan: rerata $=31,27$; rentang $26-36$. Hasil analisis bivariate menunjukkan: pertama, persepsi dan antusiasme masyarakat internal berhubungan dengan pelayanan homecare $(\mathrm{p}=0,001 ; \mathrm{r}=0,778)$. Kedua, persepsi dan antusiasme masyarakat eksternal berhubungan dengan pelayanan homecare $(\mathrm{p}=0,010, \mathrm{r}=0,754)$. Dengan demikian, tidak ada perbedaan antara persepsi masyarakat internal dan masyarakat eksternal terhadap pelayanan homecare $(\mathrm{p}=0,778)$. Kesimpulan: Persepsi dan antusiasme masyarakat berhubungan dengan pelayanan homecare. Penelitian ini memberikan informasi terhadap manajemen homecare bahwa masyarakat membutuhkan pelayanan homecare untuk meningkatkan kesehatan pasien dengan penyakit kronis.
\end{abstract}

Kata kunci: persepsi dan antusiasme masyarakat, homecare, strategi pemasaran

\begin{abstract}
Introduction: Community's Perception and enthusiasm toward homecare services becomes challenge to find out for homecare agency. An easy and effective strategy to find out is using technology information system. Methods: This study employed descriptive analysis design, in which perception and enthusiasm community were measured by completing questionnaire $(r=0.367$ validity and reliability $=0.734-0.777)$, while data analysis uses correlation product moment and T-test. Results: Univariat analysis show perception toward homecare services within internal community results in: mean $=19.8$; range 17-24, while within external community results in: mean $=19.53$; range $=15-24$. In other hand, enthusiasm toward homecare services within internal community results in: mean $=31.33$; range $=28-36$, while within external community results in: mean $=31.27$; range $=26-36$. Bivariat analysis result, first: Perceptions and enthusiasm internal community was associated toward homecare services ( $p=0.001 ; r=0.778)$. Second, Perceptions and enthusiasm external community was associated with homecare services $(p=0.010, r=0.754)$. Thereby, no difference between internal community perception and external community perception toward homecare services $(p=0.778)$. Discussion: In conclusion, this study concludes that community's perception and enthusiasm was considered related to homecare services. This study provides information for homecare management that community needs homecare services to address health improvement among patients with chronic diseases.
\end{abstract}

Keywords: community's perceptions and enthusiasm, homecare services, marketing strategy

\section{INTRODUCTION}

Home-based healthcare is a particular form of healthcare setting, which continuously and comprehensively given to individual and family to improve health status, maintain health condition, cure diseases, maximize level of independency and minimize impact of diseases, provided on their living place. The growing number of chronic disease which needs routine and long period treatment affect most of elderly, will be more appropriate to addressed by homecare treatment (Markkanen, 2008; A Lang, 2008, 2010). Therefore, it offers challenge to make homecare treatment accessible for the patients. It addressed by electronic based homecare treatment (ehomecare services) which will give significant benefit in area by its speed access. (C Liddy, 2008; S V Hoecke, 2010; SH. Landers, 2010). 


\section{The Rational Analysis on Homecare Market Potency}

Homecare as a service provider need to analyze market potency on its service. In homecare business, consumer market analysis is necessary to determine market segmentation. Market segmentation includes determine the characteristic of homecare services user. Opel (2009) mentioned social marketing strategy will deliver social issues on public service sector (such as service place, price of service, product offered, and expected health promotion) and give positive effect to product offered for the society.

Reinforcement analysis of homecare service marketing strategy is needed to determine demography characteristic of service user, cost of service, and measure user' satisfaction level of services delivered by nurses or another health profession in homecare FIKES UMM agency or satisfaction level within the service provider itself. In addition, this study were conducted to be a trigger for developing homecare in FIKES UMM by creating an e-homecare services on third year DIKTI fund service program.

According to Amirullah (2002), social issues which obtained from public sector by homecare management divided into 2 main approaches, traditional and contemporary approach. Traditional approach divided into microeconomic model and macroeconomic model. Microeconomic model explains what consumer buy and how much they buy, which in turn, macroeconomic focuses on aggregate flow in economy. In economic perspective, correlation pattern of economic condition seen in the picture below. It explains consumer feeling is the result of modification process of economic condition effect, in which noted as consumer trust level of current economic condition, and expected economic condition in the future. In other hand, contemporary approach is more focus on decision process which involves consumer to consider chosen product and services. In addition, this approach has widely developed behavioral science.

\section{Factors Affects Consumer's Behavior}

There are many factors affect consumer toward buying decision, called as behavioral factors. According to Kotler (2001), consumer buying behavior is strongly affected by cultural, social, personal and psychological characteristics. Cultural characteristic which includes cultural, sub-cultural and social class is the most influence factor toward consumer expectation and behavior. Sub-culture conducts important market segmentation to design product based on market's needs.

Social class will show chosen product and particular brand on each area. Social factor includes small group, family, role and social status of consumer. Group functioned as direct or indirect reference which creates someone attitude or behavior. Family member may influence buyer behavior. Role and status affects each other when buying something, which each role brings particular status as appreciated by society. Thereby, people frequently choose product which shows their status to society.

In addition, buying decision commonly influenced by personal characteristics such as age, life stage, job, economic condition, lifestyle, personality and self-concept. Besides that, there are another four psychology factors which affect people to choose, as motivation, perception, knowledge and believe/attitude. Motivation is leading force to satisfy every need. Perception is a process which someone choose, arrange and interpret information to create meaningful world. Knowledge is result of learning process which change people's behavior due to their experience. Through learning process, people builds particular believes and attitude. Believe will provide particular description, whereas attitude will lead to like or dislike something.

Based on correlation pattern among various business (problem) of the highest business and the lowest one, according to Amirullah (2002) consumer decision making divided into three levels; Extensive problem solving, Limited problem solving 
and Routinized response behavior. On extensive problem solving, consumer needs much information to convince their decision. Whereas, on limited problem solving, consumers do not need much information as before, yet they still keep looking for information to convince themselves. In other hand, on Routinized response behavior, since consumers have had sufficient buying experience, information is no longer needed.

Kotler (2001) describe that decision process of buying something consists of five stages as needs identification, information collection, alternative evaluation, buying decision and behavior after buying. Need identification is the first stage of decision making process which consumer identifies any problems or needs. Then, consumer feels different condition, between the expected condition and the real one. Needs appeared from either internal or internal stimulations. Next stage is gathering information process if the consumer is interested to continue buying process. Consumer may only increase their attention or actively seeking information

Information could be gain through some sources such as personal source, commercial source, public source and experience.

\section{OBJECTIVES}

This study was conducted to: 1) Identify internal and external characteristic of UMM society, 2) Identify Internal UMM society perception toward Home Care service in UMM Medical Center, 3) Identify external society perception of UMM toward Home Care service in UMM Medical Center, 4) Identify relation of internal UMM perception toward interest of Home Care service in UMM Medical Center, 5) Identify relation of external society perception toward interest of UMM of Home Care service in UMM Medical Center, 6) Identify difference perception between internal society of UMM and external society of UMM toward Home Care service in UMM Medical Center.

\section{METHODS}

The population in this study consisted of lecturers and employees of Muhammadiyah University of Malang as the internal society and the people who live around UMM campus as the external society. Then, as the nursesupporting manager, populations were the students of final semester PSIK UMM, while nurse coordinator is the lecturer of FIKES UMM.

Proportion estimation formula with $10 \%$ precision was employed to determine number of sample. It results on internal and external society samples $(\mathrm{n}=64)$, students $(\mathrm{n}=56)$, lecturers $(\mathrm{n}=24)$. Sample was chosen by simple random method. Then, those samples received questionnaire which consists of three main parts: respondent characteristic, service perception and expected homecare service. The questionnaire consists of close and open questions. (Validity test $=0,3670$, reliability $=$ $0,777$ and 0,734$)$.

Then, data were analyzed with univariat and bivariat analysis. In univariat analysis, internal and external society perception variable within interval scale is taken descriptively by counting total score. Then, the result was shown by boxplot. In other hand, public services variable within interval scale is taken descriptively by counting total score. Then, the result shown by boxplot.

In bivariat analysis, both of relation between internal society perception and interest toward Home Care service in UMM Medical Center and relation between external society perception and interest toward Home Care service in UMM Medical Center were analyzed using Pearson Product Moment correlation analysis method.

In addition, bivariat analysis was also used to test the difference between perception of internal and external UMM society toward Home Care service in UMM Medical Center using T-test independent method. 


\section{RESULT}

Table 1 shows respondents within internal society of UMM consists of 6 men $(60 \%)$ and 4 women $(40 \%)$. In other hand, the respondents within external society of UMM dominated by 12 woman $(80 \%)$ and 3 men (20\%).

Based on respondent characteristic below, most respondents within internal society of UMM were graduated from bachelor degree $(60 \%)$, while external respondents were dominated with high school degree $(40 \%)$. This table also show that internal respondents were dominated with UMM employee (60\%), whereas most of external respondents were housewives (73\%).

Perception Identification nd Preference of UMM Internal Society Interest toward Homecare Service.

Picture 1 shows mean of UMM internal society perception toward Home Care Service was 19,8 . Minimum score was 17 while maximum score was 24 . In other hand, mean score on UMM external society was 19,53. Minimum score on this group was 15 , while maximum score was 24 .

Table 2. Shows mean score of internal society preference toward supporting marketing element (including product, price,
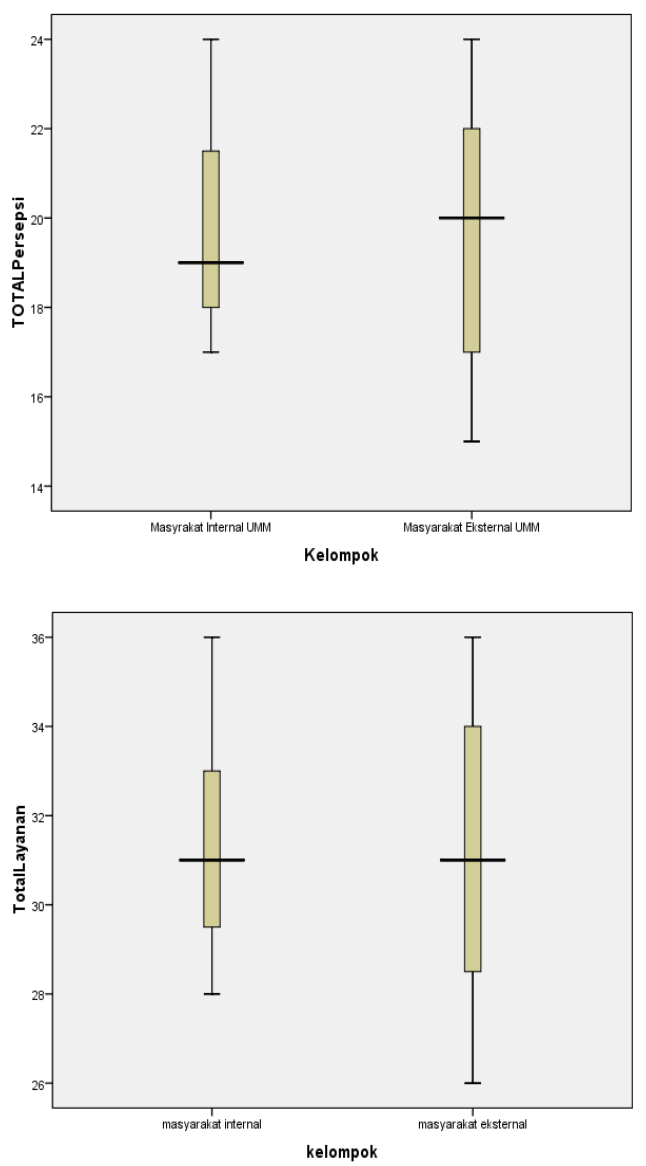

Picture 1. UMM Internal and External Society Tendency Preference and Interest toward Home Care Service in UMM Medical Center on August 2011.

Table 1. Internal and External Society Characteristic of UMM Based on Sex, Education and Job on August 2011

\begin{tabular}{llcccc}
\hline \multirow{2}{*}{ No. Characteristic } & \multicolumn{2}{c}{ Internal Society (person) } & \multicolumn{2}{c}{ External Society (person) } \\
\cline { 2 - 5 } & Frequency & $\mathbf{\%}$ & Frequency & $\%$ \\
\hline 1. Sex & & & & \\
a. Man & 6 & $60 \%$ & 3 & $20 \%$ \\
b. Woman & 9 & $40 \%$ & 12 & $80 \%$ \\
2. Education & & & & \\
a. Unfinish Elementary School & - & - & 2 & $13 \%$ \\
b. Elementary School & - & - & 1 & $7 \%$ \\
c. Junior High School & - & - & 2 & $13 \%$ \\
d. Senior High School & 3 & $20 \%$ & 6 & $40 \%$ \\
e. Diploma & 2 & $13 \%$ & 3 & $20 \%$ \\
f. Bachelor degree & 9 & $60 \%$ & 1 & $7 \%$ \\
g. Postgraduate & 1 & $40 \%$ & - & - \\
Job & & & & - \\
a. Lecturer & 6 & $40 \%$ & - & - \\
b. Employee & 9 & $60 \%$ & - & $73 \%$ \\
c. Housewife & - & & 11 & $20 \%$ \\
d. Private sector & - & & 3 & $7 \%$ \\
e. Teacher & - & & 1 & \\
& & & & & - \\
\hline
\end{tabular}


location and segmentation) was 31.33 , while mean score on external society was 31.27.

Identification of UMM Internal and External Society Perception toward Home Care service in UMM Medical Center.

\section{DISCUSSION}

\section{Characteristic of UMM Internal and External society}

Characteristic of UMM internal and external respondent was classified based on age, sex, education and job. Respondents' characteristic should be considered since it influence how people decide, including buying behavior. In this study, internal respondents which dominated with $60 \%$ men, while on external respondents was dominated with $80 \%$ women were describing gender role on perception toward particular services.

Age become an important factor on decision making and perception shaping, which also describing respondents' life stage. Internal respondents' age ranged between 24 until 28 years old, which considered as selfactualization period, so thinking process gain more mature. Moreover, since this research related to health care services which perception was analyzed based on the need of health and sick by respondents, it helped UMM external society on 35-71 year old to assess their needs based on offered services from Matahari Home Care.

Education background is another factor contributing buying behavior and perception shaping. Education background within UMM internal society which ranged from high school, diploma, bachelor, and master degree might give different perception toward something compared with UMM external society education background which the highest one was bachelor, followed by diploma, high school, elementary, even unfinished elementary school. It affects how they receive and response toward new information. Moreover, it made the informing process to UMM external society took longer time.

Another factor contributing people making decision is their job. It may describe their economic condition which shapes their lifestyle. It describes respondents' activity and their general health description. Internal society who were consist of lecturer and employee on UMM may give different contribution if compared with external society which most of them were housewives.

Above characteristics will mix up on receiving new product, leading attention to that product, interpreting and finally creating personal comment to shape particular perception of it.

\section{Identification of UMM Internal Society Perception toward Home Care Service}

UMM internal society perception gained after researcher explained Home Care services to them. They consider this service is important to improve public health condition. Real interpretation was seen on the statement that they want to ease family burden, get pleasure of being home although they are sick and consider this home care services as chosen health care alternative once they need. Their involvement on spreading information related to Home Care existence to other people was seen as positive reinforcement toward this service.

Based on this research, as a new product, Home Care has achieved particular position in public. It can be seen on UMM internal public awareness toward this product. They consider it as an alternative way of health care. This

Table 2. Correlation of Internal and External Society Perception toward Home Center Service in UMM Medical Center August 2011

\begin{tabular}{cccc}
\hline Variable & P value & Coefficient r & Correlation level \\
\hline Internal Society Perception - Home Care Service & 0.00 & 0.778 & Strong \\
External Society Perception - Home Care Service & 0.01 & 0.754 & Strong \\
\hline
\end{tabular}

Value note $\alpha 0.05$ 
positive thought will lead respondents to get on the next stage of consumer behavior called trial evaluation and adoption which unfortunately unable to be measured on this research.

\section{Identification of UMM External Society Perception toward Home Care Service}

Identification of UMM External society perception toward Home Care Services gave almost the same result with previous one. However, external society had more balance perception which shown in mean 19.53 on picture 1 , minimum score was 15 with 1 person frequency and maximum score was 24 with 1 person frequency.

Based on this study, public awareness related to Home Care services as an alternative health care has arisen nowadays. Society begin realize important role of Home Care service to public health improvement, especially external society who involved in Matahari Home Care social activity. Considered to be take care at home than hospitalized during sick and lighten family burden have lead respondents to access home care service and spread this information out.

\section{Identification of UMM Internal Society Interest toward Home Care Service in UMM Medical Center}

Identification dependent variable of Home Care Service in this research refer to the interest of respondent toward supporting marketing element (including product, price, promotion, location and segmentation) after researcher gave information. Overall, UMM internal society interest toward Home Care Service based on picture can be outlined that mean value for service variable on internal society were 31.33 . Based on calculation of computation statistical analysis, minimum value was 28 with 3 person frequencies and maximum value was 36 with 1 person frequency. To be more detail, every marketing element that becomes measurement parameter of society interest point will be explained. Those elements are product, price, promotion, location and segmentation. The element of service product marketing is the most accepted element by internal society and they agreed that the product of Home Care Service is an appropriate innovation of health service for current society. Due to its differently packed superiority compared to similar service product, Home Care Service becomes mor interesting for society.

Price of service, as illustrated in research shows the tendency of UMM internal society preference toward the element of service price. Economical aspect which seen from the spreading of respondent characteristic, $40 \%$ of internal society was ranged under 30 years old, so their need analysis is still not put priority on health-ill need. Moreover, Home Care Service which tend to new and limited and the spreading of information only by brochure and oral information is still considered less interested by UMM internal society. Therefore, more intensive promotion is needed to spread information, expand its existence. Another analysis was UMM internal society interest toward Home Care Office location. UMM internal society which consisted of UMM employee and lecturer considered its location was unreachable due to distance and tight schedule. The office location is considered less strategic, yet it only limited on the central office of Matahari Home Care. UMM internal society interest toward segmentation on Home Care Service shows that demographic factor such as income and job cannot be reference of consumer segmentation. Therefore, the service organizer could do segmentation based on another factors.

\section{Identification of External Society Interest toward Home Care Service in UMM Medical Center}

In broad outline, UMM external society interest toward Home Care Service seen on picture 5.2 result mean value of service variable in external society was 31.27 . Then, based on computer statistical analysis, minimum value was 26 with 1 person frequency and maximum value was 36 with 2 people frequency. In some respondent the researcher met, they have get on the evaluation stage of trying this new product by joining Home Care service 
after experienced available treatment when involved in the social service. More detail about UMM external society interest toward marketing element; product, price, promotion, location and segmentation of Home Care service will be explained one by one. The first marketing element is service product in form of Home Care service. UMM external society tends to have stable value than UMM internal society in form of interest on service product. It is because external society has seen physical existence of service through office infrastructure, service vehicle and another supporting factor of Matahari Home Care service when getting involved on Matahari Home Care social service activity and the real service of it. Service product offered is also as an answer of UMM external society whose healthy problem needs, as participant on Matahari Home Care social service activity, so that the product creation analysis is not much deviate from society expectation.

The second element is the price of Home Care service. UMM external society has more stable interest to the price of service than UMM internal society. It shows that despite the provided service are respondent's need, yet, based on demographic analysis which revelas $73 \%$ respondent job are housewives, the price is still burdensome compared to UMM internal society whose profession is employee or lecturer. Further analysis is needed toward society purchasing power, especially to people who need this kind of service. The next element is UMM external society interest toward Home Care service promotion. Although promotion had been created through free medical treatment social service, it still uncovering all segments, which mainly because the participant of social service is approximately 46 years old. Therefore, further socialization which more focuses on potential target is required.

UMM external society tends to be more excited toward Home Care location since they live around Matahari Home Care Center Office. UMM external society toward Home Care service similar to internal society which emphasize on segmentation should not base on income and consumer's job.

\section{Identification of Correlation Perception with UMM Internal Society Interest toward Home Care Service in UMM Medical Center}

Identification of correlation was carried out in three variables. Product moment correlation test analysis was used to determine correlation between independent variable and dependent one. First analysis was analyzing correlation of UMM internal society perception toward Home Care services. Probability count analysis reveals that $P$ value $0.00<\alpha 0.05$, so Ho is rejected or there is correlation between UMM internal society perception toward Home Care services.

Society perception is basic factor which able to push consumer to purchase or creating its consumer behavior. This perception gives strategic implication to the marketer (Hastuti, 2009). Service product is included on this exchange. In this research, internal society perception has significant influence toward Home Care service, reveal $r=0.778$ which means perception has strong effect to the service. In the context of its correlation to consumer behavior, marketing strategy effectiveness can be seen in the ability to influence and change consumer's activity to reach the target of marketing strategy. If marketing strategy directed to influence consumer's behavior, then each element in market including segmentation, price, distribution and promotion should work simultaneously in order to answer the problems related to consumer's behavior (Amirullah, 2002).

Created Internal society perception could influence the preference of buyer's interest toward the offered service. Amirullah (2002) expressed this condition occurred because consumer behavior is constructed based on the suitability of provided service to consumer need which lead to expected benefit (product-expectation). Consumer also consider of price and its change in purchasing decision (price). In addition, consumer perception toward a particular product will determine kind and form of advertisement that will be shown (promotion). Another element that support correlation pattern between consumer behavior and marketing strategy is marketing 
infrastructure support and consumer worries, doubt and uncertainty to the product, rivalry, socio cultural change and many other things are interaction form that should be understood integrally (Amirullah, 2002). All Marketing program and external factors are directed to affect consumer behavior including perception. In contrary, marketing program effectiveness can be measured from response of each consumer behavior and changing environment preference. Moreover, respondent characteristic whose education background ranged from Senior High School to Postgraduate, own stable job, age ranged 24 to 48 years old are personal factors that influence consumer behavior (Kotler, 2001).

\section{Identification of Correlation Perception with UMM External Society Preference toward Home Care Service in UMM Medical Center}

In statistical analysis, by seeing the number on column sig (2-tailed), probability score is $0,01<0,05$, then Ho is rejected or there is correlation between UMM external society perception toward Home Care service. The illustration of correlation with $\mathrm{r}$ price will be consulted. The result of statistic counting is 0,745 , so the price correlation is strong. There is correlation between UMM external society perceptions toward Home Care service on external society analysis, in which society demographic was described as own Bachelor degree to unfinished elementary school one, dominated by jobless respondent, age ranged from 35 to 71 years old as personal factors. Beside personal factors, consumer behavior is also influenced by social, culture and psychological characteristic (Kotler, 2001). Created external society perception could influence the preference of personal interest toward the service offered. Amirullah (2002) expressed this condition occurred because consumer behavior is constructed based on the suitability of provided service to consumer need which lead to expected benefit (productexpectation). Consumer also consider of price and its change in purchasing decision (price). In addition, consumer perception toward a particular product will determine kind and form of advertisement that will be shown (promotion).

\section{Identification of the Difference between UMM Internal and External Society Perception toward Home Care service}

Identification of the difference perception between UMM internal and external society was carried out by free $T$ test. The test was carried out using computer statistical analysis. The result of UMM internal and external society perception analysis is $\mathrm{P}$ value $0,778>\alpha 0,05$, so Ho is accepted which means there is no difference perception of UMM internal and external society toward Home Care service. This result shows that although different background and personal factor were exist, it cannot be reason for different perception appear. Based on picture 5.1, UMM internal society perception gained maximum mean value 19.8. Minimum value gained is 17 with 2 people frequency and the maximum value is 24 with 1 person frequency. In other hand, UMM external society perception gained mean value 19.53 . The maximum value gained is 15 with 1 person frequency and maximum value is 24 , with 1 person frequency. Although mean value is different 0.27 point, but the different value is meaningless.

\section{LIMITATION}

In this research, some limitations faced by researchers are mentioned below: a) crosssectional design which was employed in this study only carried out once, so the result was so limited and not maximum. b) Questionnaire which was used to collect data from respondents might be interpreted differently on each respondent. c) On measuring perception, the researcher did not put other factors that may influence people perception toward health care utilization, such as history of using similar health care, socio culture and so on.

\section{CONCLUSION}

Marketing effort should consider economic condition of consumer when put price on its offered services. In addition, 
as a new product, home care services need intensive promotion and socialization to let people aware their existence.

\section{RECOMMENDATION}

The nurse as the motor of Home Care service and as one of the professional staff in community should be participating in developing Home Care service. Based on the research result, the society has become aware and forming a positive perception toward Home Care service. Follow up is needed to develop the service that suitable to the need and reachable by the society and also having clearer segmentation of service management. Nurse, through Home Care service net could also participating in doing approach in improving health service (promote), preventing disease (prevention), healing disease (curative) and recovery (rehabilitation) that carried out cohesively, comprehensively, and continuously.

\section{REFERENCES}

Amirullah, 2002. Perilaku Konsumen. Yogyakarta: Graha Ilmu.

Ariella Lang, Nancy Edwards And Andrea Fleiszer. Safety in home care: a broadened perspective of patient safety School of Nursing, University of Ottawa, Ottawa, Canada. International Journal for Quality in Health Care 2008; Volume 20, Number 2: pp. 130-135.

Ariella Lang, 2010. There's no place like home: research, practice and policy perspectives regarding safety in homecare International Journal for Quality in Health Care 2010; Volume 22, Number 2: pp. 75-77.

Arikunto, Suharsimi, 2006. Prosedur penelitian edisi revisi 6. Jakarta. PT Asdi Mahasetya.

Arsanti Kurniasari, Tjahjono Kuntjoro. Pelayanan Rawat Inap Puskesmas Analisis Kebutuhan Pelanggan Puskesmas Pijoan Baru Propinsi Jambi. Working Paper Series No. 22, Juli 2006. Universitas Gadjah Mada.
Bukit, Evi Karota, 2008. Perawatan kesehatan di rumah (home health care). (Online). (http://repository.usu. sc.id/bitstream/123456789/3585/1/ evakarotabukit.pdf.Accessed on March 16 2011).

Clare Liddy, Joanne J. Dusseault Simone Dahrouge, William Hogg, Jacques Lemelin, Jennie Humbert. Telehomecare for patients with multiple chronic illnesses. Canadian Family Physician 2008; 54: 58-65. Vol. 54: January 2008

Departemen Kesehatan RI, 2009. Rencana pembangunan jangka panjang bidang kesehatan 2005-2025. (Online). (http://www.depkes.go.id/downloads/ newdownloads/rancangan RPJK 2005 2025.pdf. Accessed on 26 Maret 2011).

Direktorat Bina Pelayanan Keperawatan, 2006. Panduan pelayanan kesehatan di rumah. Jakarta. Departemen Kesehatan RI.

Douglas J. Opel, Douglas S. Diekema, Nancy R. Lee, Edgar K. Marcuse, 2009. Social Marketing as a Strategy to Increase Immunization Rates. Arch Pediatri Adolesc Med/vol 163 (no. 5).

Hidayat, Alimul Aziz, 2003. Riset keperawatan dan teknik penulisan ilmiah. Jakarta: Salemba Medika.

Hidayat, Alimul Aziz. 2009. Metode penelitian keperawatan dan teknik analisa data. Jakarta: Salemba Medika.

Homecare for senior, 2011. Benefits of senior/ elder homecare services. http://www. homecare4seniors.net/benefits.html. Accessed on March 272011.

Kementerian Kesehatan Republik Indonesia, 2009. Rancangan keputusan menteri kesehatan Republik Indonesia nomor 374/Menkes/SK/V/2009 tentang sistem kesehatan nasional, Jakarta. Kementerian Republik Indonesia.

Kementerian Pendidikan Nasional Direktorat Jenderal Pendidikan Tinggi. Pemberitahuan Hasil Evaluasi Program Pengabdian kepada Masyarakat untuk dibiayai pada tahun anggaran 2011. 4 Januari 2011.

Kotler, Philip dan Gary Amstrong, alih bahasa, Damos Sihombing. Editor. Wisnu C. Kristiaji. 2001. Prinsip-prinsip 
pemasaran edisi 8 jilid 1. Jakarta. Erlangga.

Lupiyoadi, Rambat, 2001. Manajamen pemasaran jasa: teori dan praktik. Jakarta. Salemba Empat.

Markkanen, Pi, 2008. Studying home health care nurses and aides: research design and challenges. Journal of research in nursing vol 13 (6) 480-495.

Nina Septi Wardani, 2011. Critical Activities Report in Clinical Teaching Universidade Do Minho Portugal. (Laporan aktivitas mahasiswa FIKES UMM) beasiswa Erasmus Mundus Program di Universitas Do Minho Portugal.

Parreault, William D, Joseph P. Cannon., E Jerome McCarthy, 2009. Basic marketing: a marketing strategy planning approach. New york. McGrawHill Irwin.

Pia Markkanen, Stephanie M Chalupka, Catherine Galligan, Susan R Sama, Rebecca J Gore, Hyun Kim, Anila Bello, David Kriebel and Margaret Quinn. Studying home health care nurses and aides: research design and challenges. DOI: $10.1177 / 17449871080$ 92055. Journal of Research in Nursing 2008 13: 480.

Riduwan, 2009. Dasar-dasar statistik. Bandung. Alfa beta.

Sabarinah Prasetyo, Iwan Ariawan, 2002. Biostatistika dasar untuk rumah sakit. Jurusan Kependudukan dan Biostatistik. Fakultas Kesehatan Masyarakat. Universitas Indonesia. Unpublished diktat.

Sofie Van Hoecke, Kristof Steurbaut, Kristof Taveirne, Filip De Turck and Bart Dhoedt. Design and implementation of a secure and user-friendly broker platform supporting the end-to-end provisioning of e-homecare services. Department of Information Technology, Ghent University, Belgium. Journal of Telemedicine and Telecare 2010; 16: 42-47 DOI: 10.1258/jtt.2009.001011.

Steven H. Landers, Paula Suter, Beth Hennessey, Bringing home the 'medical home' for older adults. Clavelend Clinic Journal Medicine Volume 77 Number 10 October 2010. DOI: 10.3949/ ccjm.77a.1000 